\title{
Keabsahan Poligami: Perspektif Muhammad Abduh Dan Mahmud Syaltut
}

\author{
Aunur Rofiq
}

Dosen Fakultas Ekonomi UIIS - Malang

\section{Abstract}

Polygamy nowadays becomes a hot topic which deserves great attention. From the history, it is known that it had been practiced. Several Rasuls, Ibrahim, Ya'kub, Daud and Sulaiman had more than one wife. When Islam came to Arab peninsula, polygamy was still in practice. Islam, then, provides the rules and limits people to only have four wives. This research is aimed at analyzing Abduh's and Syaltut's concepts' of polygamy. Even though the two proposed two contrasts ideas, but, seen from its norms, the two made use of justice as the main base of applying polygamy. In this sense, only few minor technical things differentiate the two concepts.

\section{Pendahuluan}

Dalam realitas sosiologis umat Islam, timbulnya kontroversi masalah poligami ini bermula pada hasil pemahaman terhadap ayat 3 dan 129 dari surah al-Nisa' ${ }^{1}$

Jika diteliti dengan cermat, ayat di atas tidak secara pasti memerintahkan juga tidak melarang poligami, karena hal seperti ini sifatnya kondisional. Penekanan al-Qur'an hanya pada tegaknya keadilan.

Ulul Albab, Vol. 3 No. 2, 2001 
Kemudian praktik ini menjadi persoalan setelah ternyata di lapangan tidak lagi memperhatikan faktor keadilan, moral dan kemampuan ekonomi laki-laki sebagaimana yang digariskan al-Qur'an. Akhirnya lagi-lagi kaum wanita yang menjadi korban.

\section{Perspektif Muhammad Abduh}

Muhammad Abduh termasuk tokoh yang sangat kritis terhadap praktik-praktik poligami yang terjadi di zamannya. Dalam mencermati masalah ini, ia tidak hanya menggunakan pendekatan normatif keagamaan, tapi juga menggunakan pendekatan sosiologis dan budaya.

Dalam masalah ini, terlihat ia lebih cenderung pada berfungsinya paradigma struktur fungsional dalam keluarga, yang mana di sana ia inginkan adanya kedamaian yang jauh dari konflik antar anggota keluarga. Untuk mewujudkan hal itu menurutnya keadilan harus menjadi common value.

Dari sanalah (masalah keadilan: red) Abduh berani mencegah praktik poligami ketika menjadi mufti (ketua dewan fatwa keagamaan Mesir), kecuali dalam kondisi yang sangat terpaksa, seperti si istri tidak bisa lagi melahirkan atau mandul (infertilitas). ${ }^{2}$

Poligami menurutnya adalah tradisi masa lampau pra Islam. Ia terkait dengan kedudukan wanita yang dipandang sebagai satu eksistensi antara manusia dan hewan.

Poligami juga merupakan bentuk pelecehan terhadap wanita. Bagi Abduh pada dasarnya tidak ada seorang istri yang rela, jika ada wanita lain yang hendak merebut cinta suaminya darinya. Dalam kondisi seperti ini istri akan dihadapkan pada dua kemungkinan; sakit hati karena terbakar oleh rasa cemburu, atau tidak demikian dengan berbagai sebab yang mengiringinya. Begitu juga sebaliknya, seorang suami tidak akan menerima jika ada laki-laki lain yang hidup bersama istrinya. Itulah fitrah manusia. Seandainya ada seorang istri atau suami yang rela jika pasangannya berbagi cinta dengan yang lain, berarti ada yang tidak wajar. ${ }^{3}$

Abduh juga mengibaratkan kehidupan berpoligami itu seperti kehidupan satu ayam jantan dengan sepuluh ekor betina, di mana si jantan tidak bisa membagi 
cinta secara adil di antara sepuluh betina tersebut, artinya kecenderungan berlebih akan selalu ada terhadap salah satu betinanya.

Jika ada yang mengatakan bahwa pengalaman menunjukkan adanya kemungkinan memadu dua istri atas lebih, dengan dukungan istri yang ada secara suka rela. Jawabannya kata Abduh bisa dilihat dari dua sisi:

Pertama, jikalau benar demikian, hal seperti itu jarang adanya. Maka sudah tentu sesuatu yang jarang tidak bisa dijadikan pegangan untuk diterapkan di tengahtengah umat. Padahal kasus-kasus destruktif yang terjadi dalam poligami tidak terhitung jumlahnya. Orang yang mengatakan tentang kerelaan dan ketenangan istri-istri itu dengan satu suami berarti ada sesuatu yang tidak wajar.

Kedua, di kalangan istri-istri, kerelaan seperti itu memang jarang terjadi, namun di kalangan wanita penghibur yang suka berganti laki-laki, rasa suka rela seperti itu sudah biasa. ${ }^{4}$

Sikap Abduh yang begitu "radikal" dalam masalah ini sejak ia menjadi Pemred "al-Waqâ'i" al-Mishriah"; dan tidak pernah berubah hingga akhir hayatnya.

Menurutnya keadilan merupakan syarat mutlak poligami. Dan keadilan dalam hal ini bukan perkara sepele. Benar syari'ah mentolerir suami memiliki empat istri, jika ia melihat dirinya mampu untuk berbuat adil. Namun jika tidak, maka ia harus konsisten dengan satu istri. ${ }^{6}$

Abduh menolak jika dikatakan bahwa ketidakadilan yang sering terjadi itu hanya terbatas di kalangan orang-orang miskin dan kurang berpendidikan. Lain halnya dengan kalangan orang-orang kaya dan pejabat, mereka justru menafkahkan hartanya secara berlebih terhadap istri-istrinya yang dicerai dan yang masih dipertahankan. Begitu juga terhadap anak-anak mereka. Karena itu tidak ada halangan bagi mereka untuk berpoligami selama dalam batas-batas ketentuan syara'. Bahkan poligami bagian dari sunnah Rasulullah saw. "Kawinlah dan perbanyaklah keturunan, karena saya akan gembira dengan banyaknya umatku di hari kiamat nanti." Ketidakadilan yang terjadi di kalangan orang miskin itu tidak bisa dijadikan dasar untuk melarang sunnah Rasul dan salaf al-shaleh tersebut. Adapun ayat:" Fa ankihù mâ thâba lakum min al-nisâ' matsna wa tsulâsâ' wa rubấ '... dalam Qs. 4: 3, menurut ijma` tidak mansukh. Jadi masih bisa diamalkan sesuai teksnya. $^{7}$ 
Statemen di atas kata Abduh tidak benar. Kasus yang terjadi di kalangan hartawan dan pejabat tentang pengusiran istri-istri beserta anak-anaknya cukup banyak. Juga tidak sedikit orang-orang seperti itu yang mengusir anak-anak mereka demi istri barunya. Kami melihat lanjut Abduh, pemberian nafkah dan hak istri lainnya yang mereka lakukan belum pada tingkat keadilan seperti yang diinginkan syara'. Jika demikian adanya, orang-orang kaya tersebut sama saja dengan si miskin dalam melakukan pelanggaran agama. Bahkan pelanggaran yang dilakukan orangorang kaya lebih parah ketimbang mereka yang miskin. Kasus istri yang dibiarkan terkatung-katung selama setahun, dua tahun bahkan sampai sepuluh tahun, dengan alasan khawatir adanya kecenderungan cinta yang berlebihan terhadap salah satu istrinya adalah salah satu contohnya. Sementara mereka (istri) tidak berani menuntut cerai karena takut akan keselamatan dirinya yang akan ditimpakan suami yang kaya dan berkedudukan itu. Maka dengan terpaksa mereka tetap meringkuk dalam kehidupan yang tidak pantas seperti itu. ${ }^{8}$

Lain kasus adalah kondisi pendidikan anak yang tumbuh di tengah kedengkian saudara-saudara tirinya, dan permusuhan bapaknya sendiri juga sering terjadi di kalangan orang kaya yang berpoligami. Kasus seperti ini lanjut Abduh banyak kita saksikan di dunia Timur, termasuk Mesir. Mereka itu seakan tidak memahami hikmah Allah dalam hal ini. Bahkan justru menjadikannya sebagai jalan pemuas nafsu seksual. Hal seperti inilah yang ditolak agama dan akal sehat. ${ }^{9}$

Bagi Abduh ada dua alternatif bagi seorang suami: Pertama, kawin dengan satu istri jika tidak mampu berlaku adil, sebagaimana isyarat ayat "fa in khiftum...." Adapun kalimat" fa ankihû... " yang disebut selanjutnya terikat (muqayyad) oleh kalimat sebelumnya. Kedua, berfikir ulang secara jernih dan hati-hati tentang keadilan yang menjadi syarat mutlak agama, keutuhan dan kasih sayang antar anggota keluarga, beban yang akan ditanggung istri dan anak-anak jika terjadi perceraian, serta perlindungan mereka dari hal-hal yang tidak pantas terjadi. Itu semua harus ditimbang sebelum melakukan poligami. Jika itu yang dilakukan lanjut Abduh, maka ia termasuk bagian dari para suami yang bertakwa kepada Allah, yaitu suami yang menghormati undang-undang keadilan, melindungi kehormatan dan hak-hak istri, menggaulinya dengan cara yang ramah, lembut dan baik, dan tidak berlaku diskriminatif. Itulah suami-suami mulia. Jika seperti itu adanya tidaklah mengapa ia berpoligami, walaupun sangat jarang menemui orang seperti mereka di berbagai tempat. Namun jika ia melanggar ketentuan syara', hakim berhak 
menghukumnya. Apa hukumannya? Agama tidak memberi ketentuan khusus. Hal itu tegantung kondisi dan tradisi setempat. ${ }^{10}$

Kembali pada masalah keadilan yang menjadi syarat mutlak poligami itu. Menurut Abduh orang yang tidak mampu memberikan hak-hak mereka (istri), atau jika suami cenderung kepada salah satu istrixya berarti ia telah melangkahi hak yang lain. Dengan demikian ia telah menghancurkan sistern keluarga, padahal asas pembinaan keluarga yang baik adalah kesatuan dan kasih sayang di antara anggota keluarga.

Adalah Rasulullah saw. tetap melakukan giliran di antara istri-istrinya walaupun dalam keadaan sakit, yang demikian dilakukan demi menjaga tegaknya keadilan. Beliau tidak ingin berdiam diri di rumah salah satu istrinya saja tanpa kerealaan yang jelas dari mereka. Karenanya beliau tetap minta izin kepada mereka ketika hendak tinggal di rumah Aisyah selama beliau sakit. ${ }^{11}$

Abduh lalu mengutip beberapa riwayat tentang nasehat/wasiat terakhir Rasulullah saw:" Bahwa Rasulullah pernah berwasiat tentang tiga perkara yang selalu diulang-ulang hingga suaranya habis, yaitu: pertama, shalat; kedua, hamba (pembantu), jangan kalian membebani mereka di luar batas kemampuannya; dan ketiga, tentang istri yang dinikahi dengan amanah Allah dan menjadi halal kehormatannya dengan menyebut kalimat-Nya". Riwayat lainnya adalah "Siapapun yang beristri dua lalu lebih cenderung kepada salah satunya -dalam satu riwayat dengan redaksi: tidak berbuat adil-maka pada hari kiamat kakinya akan pincang". Selanjutnya Abduh mengutip riwayat tentang "keluhan" Rasulullah: "Ya Allah, keadilan dalam melakukan giliran dan nafkah adalah kerja kerasku yang mana aku sanggup melakukannya. Namun aku tidak kuasa untuk melakukan apa yang menjadi milik-Mu (kecenderungan hati)." Begitu juga jika Rasul hendak berpergian, beliau selalu mengundi istri-istrinya, siapa di antara mereka yang boleh ikut. Kemudian lanjut Abduh, apakah setelah adanya peringatan syari'ah -yang tidak bisa ditawar itu- seorang suami akan tetap berpoligami, padahal ia tidak mampu untuk itu? ${ }^{12}$

Walaupun Abduh sangat keras tentang masalah ini, ia tetap konsisten pada rasionalitas dan faktor kondisi yang tidak bisa dilepaskan dari penerapan hukum. Karenanya ketika menafsirkan ayat "wa lan tastathi $\hat{u}$ an ta'dil $\hat{u}$ baina alnisấ ' walau harashtum", (Qs. 4: 129) ia mengatakan bahwa ayat ini terkait dengan keadilan dalam kecenderungan hati. Jika tidak demikian niscaya poligami akan terlarang apapun alasannya. Namun ternyata ayat "fa lâ tamîlû kulla al-maili 
fatadzarûhâ kâ al-mu 'allaqah" selanjutnya menunjukkan bahwa dalam masalah kecenderungan hati, Allah tidak akan menghukum hamba yang tidak mampu melakukan sesuatu yang di luar batas kemampuannya. Rasulullah juga pernah seperti itu, di akhir hayatnya kecenderungannya terhadap Aisyah melebihi istriistri lainnya. Namun beliau tidak pernah berlaku diskriminatif, yaitu selalu melibatkan mereka dalam masalah keluarganya. ${ }^{13}$

Sungguhpun demikian lanjutnya, orang yang merenungkan dua ayat (Qs. 4: 3,129 ) itu, niscaya ia akan mengerti bahwa poligami dalam Islam adalah perkara yang sangat berat, tidak bisa dilakukan kecuali dalam keadaan sangat terpaksa. Dan orang yang hendak melakukannya disyaratkan memiliki keyakinan yang sangat kuat akan kemampuannya menegakkan keadilan. ${ }^{14}$

Imarah mencatat beberapa alasan sehingga Abduh begitu keras dalam masalah ini:

Pertama, kebiasaan kawin dengan banyak istri adalah bukan ciri khas orangorang Timur an sich, seperti Tibet atau Mongol misalnya. Baratpun pernah mengenal seperti itu, seperti Jerman. Bahkan Sebagian paus pernah membolehkannya untuk para raja pascamasuknya agama kristen ke Eropa. Yang demikian terjadi setelah Islam ada. Artinya aturan seperti itu sangat kondisional dan kontekstual, bukan hanya milik orang-orang Timur. la akan lenyap bersama lenyapnya kondisi pendukungnya.

Kedua, berkembangannya sistem poligami berkait dengan pertumbuhan jumlah wanita yang melampaui jumlah laki-laki dalam beberapa komunitas perang masa lalu, salah satunya adalah masyarakat Arab awal. Biasanya pendukung berlakunya sistem ini dalam masyarakat seperti itu mereka yang memiliki kekuasaan dan harta.

Ketiga, Islam berbeda dengan apa yang dituduhkan para orientalis bahwa agama ini mengadopsi sistem ini dari tradisi jahiliyah. Justru menurut Abduh sebaliknya, Islam mengambil sikap reformis terhadap masalah ini. Tujuannya jelas menghapus sistem ini dengan pendekatan bertahap (ladarruj). Karenanya ketika ada yang masuk Islam dengan sepuluh istri, Rasulullah Saw. membatasinya hanya empat. Kesalahan orientalis tersebut bertolak dari pandangan mereka terhadap fenomena umat Islam yang mereka teliti, kemudian secara serampangan memberikan konklusi bahwa yang demikian adalah agama. 
Keempat, pembatasan di atas juga dimaksudkan untuk memberikan jalan keluar dari praktik-praktik ketidakadilan yang menimpa anak yatim. ${ }^{15}$

Biasanya dulu anak yatim menjadi korban para pengasuhnya. Mereka mengawinya karena rakus terhadap hartanya. Oleh karena itu Islam mengajarkan kepada kaum patriarki (pengasuhnya) agar tidak seperti itu:" Jika kelemahan anak yatim itu dapat menyebabkanmu terjatuh dalam kezhaliman ketika mengawininya, maka kawinlah dengan wanita-wanita baik-baik yang cantik dan berharta lainnya, satu sampai empat yang kiranya cocok untuk kalian. Permasalahan ini perlu dilihat dari ilustrasi seperti ini kata Abduh.

Kelima, Islam menurut Abduh telah mematok syarat berlakunya keadilan secara mutlak. Seandainya seseorang memiliki prasangka sedikit saja akan ketidakmampuannya, maka ia harus kawin satu. Poligami yang disebutkan di ayat itu tidak berarti memberikan stimulus (targhîb) tapi menunjukkan sikap yang tidak disukai (tarhîb. Jika orang yang hendak berpoligami itu berfikir tentang syarat keadilan tersebut niscaya ia hanya kawin satu.

Keenam, di masa Abduh dalam masyarakat Islam, praktik poligami identik dengan sistem perbudakan. Islam menurutnya tidak mengajarkan seperti itu. Abduh membedakan antara tawanan perang yang didapat dari peperangan membela agama dengan sistem perbudakan yang pernah dilakukan oleh sebagian umat Islam. Hal itu bagi Abduh adalah tradisi jahiliyah, tidak ada hubungannya dengan Islam.

Ketujuh, boleh-boleh saja menurutnya (Abduh), melarang praktik poligami. Pernyataan ini diungkapkan ketika menjawab pertanyaan tentang boleh tidaknya mencegah poligami. Yang demikian menurutnya karena keadilan adalah syarat mutlak yang harus dipenuhi, padahal berlakunya keadilan seperti itu bisa dikatakan "tidak ada". Sungguhpun ada orang yang bisa berbuat adil, itupun jarang, karenanya sesuatu yang jarang itu tidak bisa dibuat pegangan. Di samping itu poligami secara fakta dapat mengundang sengketa antar istri, begitu juga antar anak-anaknya. Atas dasar itu Abduh menganjurkan agar poligami dilarang, kecuali dalam keadaan yang sangat darurat seperti penyakit mandul . Jika persoalannya demikian maka si hakim perlu membantunya. ${ }^{16}$ 


\section{Aunur Rofí}

\section{Mahmud Syaltut: Poligami perlu disubsidi}

Lalu bagimana pandangan Syaltut? Syaltut dalam masalah ini tidak seradikal Abduh, namun secara umum bisa dikatakan sama dalam mengambil konklusi, yaitu berlakunya keadilan. Perbedaannya terletak pada prosesnya, yaitu apakah dibolehkannya berpoligami itu karena terpaksa atau tergantung pada kemauan tiap individu?

Untuk lebih jelasnya baiklah dipaparkan di sini pemikiran Syaltut. Persoalan ini kata Syaltut telah banyak mengundang pembicaraan di antara peneliti keagamaan dan sosial. Para peneliti keagamaan ketika merespon teks-teks ayat poligami tersebut berpandangan bahwa asal poligami terlarang kecuali terpaksa. Yang lain melihat bahwa poligami pada asalnya sah-sah saja dipraktikkan kecuali di sana ada kekhawatiran bahwa sisi negatifnya lebih dominan dari positifnya.

Menurut Syaltut, Islam dan bangsa Arab adalah salah satu di antara agama dan bangsa-bangsa dunia yang pernah melegalkan poligami. Poligami adalah bagian dari sejarah kehidupan manusia. Tidak sedikit para nabi sebelum Muhammad Saw. yang telah melakukan praktik ini. ${ }^{17}$

Dua ayat Qs. 4:3, 129 di atas menurutnya selalu relevan dengan hikmah pemberlakuan syari'at ( $h i k m a h$ al tasyri') dalam masyarakat. Jika dua ayat tersebut dipahami secara parsial akan menghasilkan pemahaman bahwa keadilan pada ayat "fa in khiftum an lâ ta "dilû fawâhidatan", itu adalah suatu kewajiban yang tidak bisa ditawar. Lantas terlintas dalam benak bahwa keadilan dalam pengertiannya yang sempurna adalah keadilan yang mesti direalisasikan secara sempurna pula dalam segala aspeknya. Dengan ketentutan seperti ini kata Syaltut, orang-orang mukmin merasa kesulitan melaksanakannya, karena keadilan seperti itu ada di luar batas kemampuan mereka. Benarkah keadilan seperti itu yang dimaksud? Ternyata tidak lanjut Syaltut, sebab ayat yang kedua (Qs. 4:129) mengajarkan bahwa keadilan dalam berpoligami yang dimaksud itu tidak seperti yang digambarkan. Artinya yang dilarang adalah kecenderungan yang berlebih-lebihan kepada salah seorang istrinya, kemudian menelantarkan yang lain. ${ }^{18}$

Ayat pertama dan kedua saling berjalinkelindan dalam meletakkan dasar poligami. Di atas dasar inilah Rasulullah, para Sahabat, Tabi'in, dan kaum muslimin melakukan poligami. Adapun tentang persoalan, apakah keadilan itu bisa terealisir atau tidak, diserahkan pada masing-masing individu. Merekalah yang tahu kondisi 
dirinya. Undang-undang penguasa tidak bisa intervensi terhadap mereka, lain halrya jika terjadi pelanggaran hukum secara jelas yang mereka lakukan terhadap istrinya, dan hubungan suami istri tidak bisa dipertahankan lagi, barulah hakim (qadli) boleh intervensi. ${ }^{19} \mathrm{Jadi}$, kawin lebih dari satu boleh-boleh saja dilakukan selama seseorang tidak takut berbuat zhalim terhadap istrinya, jika takut perbuatan itu terjadi hendaklah ia berlindung diri dari dosa, dan tetap berpegang pada satu istri.

Di sinilah letak perbedaan Abduh dan Syaltut. Perbedaan itu juga tampak jelas dalam statemen Syaltut yang sangat toleran dalam masalah ini. Menurutnya legalnya berpoligami juga tidak bergantung pada adanya istri yang sudah tua, mandul atau kerena kuantitas wanita melebihi jumlah laki-laki. Yang penting dalam poligami memenuhi syarat seperti kawin dengan istri yang pertama, yaitu mampu membayar mahar dan nafkahnya secara adil. Jadi dibolehkannya berpoligami itu adalah bukan karena terpaksa. Ayat di atas tidak menunjukkan hal itu, seandainya demikian niscaya Nabi Saw. akan menjelaskn kepada orang-orang yang baru masuk Islam bersama istri-istrinya yang lebih dari empat itu bahwa kawin dengan empat istri atau lebih dari satu tidak apa-apa dengan syarat; si istri sudah tua, sakit, si suami mempunyai kemampuan mendidik semua anaknya yang lahir dari istri-istrinya, juga mampu memberi nafkah kepada yang berhak menerimanya termasuk seluruh sanak keluarga dekatnya. Ternyata hal itu tidak dilakukan oleh Nabi, ini menunjukkan bahwa poligami tidak ada hubungannya dengan keterpaksaan. ${ }^{20}$

Syaltut juga melihat, semula poligami dilegalkan untuk memberikan jalan keluar pada pengasuh anak yatim agar tidak terjatuh dalam kezhaliman akibat perlakuannya yang tidak adil terhadap mereka. Dan redaksi "berpegang pada satu istri" diungkapkan ketika timbulnya ketakutan terhadap ketidakadilan pada istriistrinya yang telah disebutkan oleh ayat sebelumnya. Dari sini dapat dikatakan lanjut Syaltut, yang penting adalah keadilan, itulah syarat dibolehkannya poligami, bukan keterpaksaan. ${ }^{21}$

Tidak sedikit memang yang menuntut pembatasan bahkan pelarangan poligami. Salah satunya adalah dari pihak Departemen Urusan Sosial Mesir (1945). Di antara tuntutunya yaitu: izin dari Pengadilan Agama setelah adanya penelitian terhadap yang hendak berpoligami, baik yang berkaitan dengan moralitas, kemampuannya dalam bergaul dengan istri, dan tangungjawab nafkah yang tidak hanya untuk orang-orang yang ada dalam tanggungannya tapi juga untuk sanak keluarganya. 


\section{Aunur Rofiq}

Adanya tuntutan seperti ini berangkat dari asumsi bahwa poligami berbahaya terhadap kehidupan keluarga, semakin membebani pemerintah akibat banyaknya orang-orang yang terusir-baca: terlantar- dari keluarga, memutuskan tali silaturrahmi, cenderung melalaikan pendidikan anak. ${ }^{22}$

Tapi kata Syaltut, tuntutan seperti ini tidak objektif dan cenderung melalaikan sisi-sisi positif poligami. Sebelum melontarkan tuntutan tersebut, mestinya mereka (para penuntut) itu menimbang sisi baik buruknya poligami seperti yang selalu dilakukan dalam melihat suatu persoalan. Setelah jelas persoalannya (tentang baik dan buruknya) baru melakukan sosialisasi, bahkan melegalkannya dalam undangundang.

Menurut kaidah lanjut Syaltut, sesuatu yang memiliki kebaikan -baca: sisi positif- pen- yang lebih secara kualitas dan kuantitasnya dari pada kejelekannya, maka yang menjadi pegangan adalah sisi positifnya. Kejelekan yang minimal itu tidak akan menjadi beban bagi pelegalan hukum yang diambil dari sesuatu yang sisi kebaikannya lebih banyak. Bagaimanapun dua sisi itu akan selalu ada dalam pemberlakuan undang-undang, walaupun sangat kecil kuantitas kejelekannya. Kehidupan dunia ini pun demikian, tidak pernah terlepas dari dua sisi tersebut. Namun hukum tetap diberlakukan. ${ }^{23}$

Syaltut "menuding" bahwa mereka memanipulasi makna keadilan ( $a d l$ ) yang termaktub dalam ayat: "Fa inkhifium an lâ ta'dilû fa wâhidatan." Menurut mereka poligami tidak dibenarkan kecuali tidak takut berbuat zhalim, baik terhadap para istri ataupun lainnya. Dengan demikian mereka berasumsi adanya izin berpoligami dan tuntutan-tuntutan lainnya di atas harus dilakukan. Pemikiran seperti ini aneh ujar Syaltut. Keadilan yang dimaksud dalam ayat tersebut adalah khusus terhadap istri, seperti penjelasan ayat: "Wa lan tastathi $\hat{u}$ an ta dilû baina al nisâ" "dan hadits-hadits yang berkaitan dengan pembagian di antara istri. ${ }^{24}$ Menurutnya tak satupun fuqaha' ${ }^{25}$ berpendapat bahwa keadilan tersebut mencakup sebagaimana yang menjadi tuntutan di atas. Jadi maksud keadilan -yang diinginkan oleh ayat dan hadits- adalah keadilan di mana yang kaya dan miskin dapat merealisasikannya sesuai dengan kondisinya masing-masing. Yang terpenting adalah hendaknya kecenderungan yang ada terhadap salah satu istrinya tidak sampai menelantarkan istri yang lain. Dengan interpretasi seperti ini, nampak bahwa mereka (para penuntut) itu melihat keadilan tidak pada tempatnya. ${ }^{26}$ 
Syaltut juga membantah jika dikatakan poligami berkait dengan sebab-sebab terlantarnya keluarga. Menurutnya dalam statistik hasil penelitian di Mesir menunjukkan bahwa keterlantaraan yang disebabkan oleh faktor poligami hanya ada $3 \%$. Hal ini sama dengan prosentase kekerasan terhadap anak kecil dalam keluarga, dan kekerasan tuan rumah terhadap pembantu. Sebuah prosentase yang sangat kecil untuk menklaim praktik poligami sebagai penyebab utama terlantarnya anggota keluarga tersebut. Apalagi kalau dasar tersebut dijadikan alasan untuk membatasi poligami, padahal poligami juga banyak memiliki manfaat bagi kehidupan sosial..$^{27}$

Faktor-faktor lain yang berpotensi menjadi sebab keterlantaraan adalah seperti kemiskinan, jeleknya pendidikan anak, kekerasan dalam perburuhan dan pembantu rumah tangga, perlakuan ibu/bapak tiri, lingkungan yang rusak, penyakit yang menimpa anak kecil akibat ketidakmengertian orang tua terhadap masalah kesehatan, dan sebab-sebab lainnya yang tidak dapat disebutkan. Semua itu menurut Syaltut harus dicarikan solusinya. Pemerintah yang baik adalah yang berorentasi pada kemaslahatan rakyat dan membantunya memerangi sebab-sebab tersebut.

Adapun tentang poligami, tidak realistis untuk mencegahnya hanya dengan sebab kecil yang ditimbulkannya seperti tesebut terdahulu, apalagi jika ini dikaitkan dengan problema "kumpulkebo", penguburan hidup-hidup janin yang ditemukan polisi dan masyarakat yang sebagian besar akibat penolakan terhadap lembaga perkawinan, serta banyaknya wanita menjanda. ${ }^{28}$

Syaltut mengajak untuk mngambil pelajaran dari Prancis yang memiliki masalah besar dengan gaya hidup yang dijalani laki-laki dan wanita di sana, khususnya sikap mereka terhadap perkawinan dan poligami. Pada tahun 1901 Prancis pernah mengadakan konfrensi untuk mencari jalan terbaik dalam menghadapi merebaknya kejahatan dan anak pungut akibat terlantar dan tidak jelas orang tuanya. Salah satu pembahasan penting dalam konfrensi ini adalah tentang anak-anak yang tidak jelas orang tuanya (hasil kumpulkebo). Dalam penelitian yang dikutip Syaltut, terdapat suatu kesimpulan menarik bahwa ternyata hal itu berkait dengan penolakan para pemuda untuk kawin, dan larangan atau pembatasan poligami. ${ }^{29}$

Di lain pihak, Syaltut menyayangkan sikap penguasa Mesir yang pernah memberlakukan undang-undang yang melarang praktik poligami (1926). Sehingga dalam waktu delapan tahun saja pemerintah dikejutkan oleh banyaknya jumlah 


\section{Aunur Rofía}

bayi yang lahir secara tidak jelas, istri-istri yang dikawin secara simi, dan banyaknya anak-anak meninggal yang disembunyikan.

Rupanya Syaltut bersikukuh untuk tetap membiarkan poligami berjalan sebagaimana mestinya. Baginya poligami merupakan jalan keluar terbaik untuk mengantisipasi masalah-masalah sosial di atas. Karenanya ia berani membuat terobosan kontroversial dalam masalah ini. Menurutnya untuk melindungi umat dari perbuatait yang tidak diinginkan itu, pendidikan akhlak perlu ditingkatkan. Kemudian, tidak lagi berfikir bagaimana mencegah poligami, tapi bagaimana membatasi kehidupan membujang. Selanjutnya merumuskan undang-undang terbalik, yaitu memberikan subsidi kepada mereka yang berpoligami baik dalam hal nafkah untuk istri maupun untuk anak-anaknya, jika mereka bukan orang yang kaya. Karena dari beberapa catatan terdahulu poligami justru memberikan sumbangsih konstruktif terhadap perkembangan akhlak dan kehidupan sosial ujarnya. ${ }^{30}$

Nampaknya tegaknya keadilan menjadi fokus kesepakatan di antara guru dan murid di atas dalam masalah ini, walaupun dalam prosesnya berbeda.

Hemat Penulis respon Abduh yang sangat kritis dan "radikal" di atas menggambarkan keseriusannya dalam merespon tradisi negatif poligami dalam masyarakat yang bias gender saat itu dan cenderung mengedepankan aspek seksualitas dari pada sens of solidarity. Akibatnya tidak sedikit istri yang dirugikan. Kondisi seperti ini juga "mengundang" Qasim Amin, salah seorang murid Abduh melontarkan kritikan kerasnya. Menurutnya jika poligami menjadi sarana penindasan terhadap perempuan (istri) seperti jaman kita (Amin) ini, dan pelanggaran terhadap ketentuan syari'at serta menimbulkan konflik antar anggota keluarga maka hakim boleh melarang praktik ini selama sejalan dengan prinsip kemaslahatan. ${ }^{31}$

Pandangan Abduh dan Amin di atas tidak bisa dipahami secara normatif, karena terkait dengan faktor sosiologis dan kontekstual. Jika itu (pemahaman normatif) yang dilakukan maka konsekwensinya adalah: pertama, dua tokoh tersebut akan menjadi orang yang "tertuduh" sebagai ulama' yang anti poligami. Kedua, poligami akan menjadi praktik terlarang walaupun dalam kondisi yang berbeda dengan saat itu -masa Abduh. Jika hal ini yang terjadi, maka masalahnya adalah bagaimana dengan kuantitas kaum wanita yang jaub melampaui laki-laki; janda salehah yang miskin yang memiliki anak-anak yang cerdas dan berpotensi ${ }^{32}$; "kumpul 
kebo"; anak-anak yang terlantar tanpa tahu siapa bapaknya; penyelewengan suami dan lain-lainnya? ${ }^{33}$

Georges Anquetil, sosiolog Prancis dalam bukunya" La Maitresse Legimitime " menunjukkan perlunya Eropa metetapkan poligami melalui undangundang. Kemudian ia menyinggung beberapa tokoh besar dunia yang menjadi pendukung institusi ini seperti Plato, Ariestoteles, Bacon, August Comte -dari kalangan Filosof-; Alexander, Cesar, Napoleon dan Nelson -dari pihak militer-; Goethe, Burns, Byron, Hugo - dari kalangan penyair-; dan Percles Mendes, Buckingham, Mirabeau atau Gambetta -dari kalagan negarawan. ${ }^{34}$

Jika Abduh yang begitu keras terhadap praktik poligami memiliki social background dunia Islam, khususnya Timur Tengah -baca: Mesir-, maka Anquetil yang mendukung institusi poligami juga demikian -background Eropa-Prancis khususnya.

Bagi Anquetil, dukungannya terhadap poligami karena menurutnya poligami memiliki fungsi sosial yang sangat signifikan dalam mengentaskan penyakit sosial. Di antaranya adalah: Pertama, poligami dapat menekan merajalelanya prostitusi. $K e d u a$, dengan poligami salah satu sumber penyakit kelamin yang dapat membunuh anak bangsa dapat ditekan. Ketiga, poligami memungkinkan jutaan kaum wanita dapat mempergunakan haknya akan kecintaan dan keibuan, yang kalau tidak, akan terpaksa hidup melajang dalam kungkungan sistem monogami. Keempat, poligami akan mengurangi sebab-sebab drama perceraian yang tak terhitung banyaknya; kejahatan-kejahatan karena hubungan seksual yang ilegal; kemunafikan dalam rumah tangga; bencana merosotnya jumlah penduduk; pembunuhan anak-anak; dan penitipan bayi ke panti asuhan. Kelima, dengan poligami suami dapat menjaga kesehatan istrinya yang hamil dan bersalin; melindungi dirinya dari petualanganpetualangan bersama wanita panggilan yang jumlahnya sudah maklum di Paris, di mana dua pertiga di antaranya mengindap menyakit syphilis. ${ }^{35}$

Selanjutnya kita akan mencermati gagasan kontroversial Syaltut tentang subsidi bagi pelaku poligami. Gagasan ini merupakan anti tesis dari respon Abduh di atas yang terlalu ketat -untuk tidak mengatakan melarang. Namun jika ide ini dipraktikkan tanpa kontrol dan seleksi yang ketat terhadap pelaku poligami, akibatnya juga akan kontra produktif. Bahkan bukan tidak mungkin poligami menjadi wadah pemuas nafsu laki-laki, dan tumbuhnya keluarga yang penuh konflik, persaingan tidak sehat, khususnya di kalangan sesama istri yang dimadu. Biasanya faktor 


\section{8}

\section{Aunur Rofia}

terpenting yang menjadi pemicunya adalah memperebutkan cinta dan perhatiaan suami.

Hal seperti ini menurut Bintu Syâthi' juga pernah terjadi dalam rumah tangga Nabi saw. Jika saja belaiu bukan tipe manusia sempurna niscaya "bahtera keluarga nubuwah" tersebut sulit untuk dipertahankan keseimbangannya -untuk tidak mengatakan "broken home". Itulah sebabnya mengapa Allah SWT. memberi peringatan keras-Nya terhadap mereka. ${ }^{36}$

\section{Penutup}

Boleh tidaknya poligami sangat kondisional. Al-Qur'an tidak secara tegas melarang atau memerintahnya. Yang menjadi perhatiannya adalah tegaknya keadilan. Karena itu persoalan ini perlu didekati dengan pendekatan kontekstual -sosiologisbukan normatif-teologis. Soal pelegalan poligami atau melarangnya adalah soal teknis yang tergantung pada kondisi dan tempat tertentu.

Ayat Qs. 4:3 tersebut diturunkan menyusul berakhimya perang Uhud yang banyak menelan korban dari pihak kaum muslimin 70 orang dari 700 pasukan laki$\mathrm{laki}^{37}$. Waktu itu banyak Muslim perempuan yang menjadi janda dan anak-anak perempuan yang yatim. Dalam konteks sosial yang berlaku saat itu jalan terbaiknya memperbolehkan poligami dengan janda dan anak-anak perempuan yatim, dengan syarat banya empat istri dan mampu berlaku adil. ${ }^{38}$

Parvez seorang mufassir terkemuka Pakistan berkomentar bahwa pembolehan kawin dengan lebih dari seorang istri tergantung pada dua kondisi: Pertama, jika ada ekses dari perempuan lajang atau tanpa suami dalam masyarakat dan tidak ada solusi lain yang masuk akal, maka perkecualian dapat dibuat terhadap aturan monogami dan seorang laki-laki dapat mengawini peremmpuan yang (tanpa suami) itu. Kedua, pembolehan ini juga dengan persyaratan bahwa keadilan diberikan kepada semuanya dalam keluarga. Juga harus memungkinkan bahwa untuk memikul beban atas semua anak yang dilahirkan pada istrinya. Ia tidak boleh menjadi beban tak terpikulkan baginya ${ }^{39}$ Wa Allâhu a'lam bi al-shawâb! 


\section{Endnotes}

1 Ayat 3 dari Surah al-Nisa' di atas Turun berkenaan dengan kasus seseorang yang hendak mengawini anak yatim yang ada dalam asuhannya, karena harta dan kecantikannya. Aisyah memahami ayat ini dengan pengertian bahwa jika para pengasuh anak-anak yatim tersebut khawatir dengan mengawini mereka, mereka tidak akan mampu berlaku adil, mereka sebaiknya mengambil wanita lain. Lihat Zaki al-Din Abdu al-'Ahzim al-Mundziri, Mukhtshar Shahih Muslim 1996, Riyadl: Dar al-Salam li al-Nasyr wa al Tauzi“, dalam bab tafsir surah al-Nisa', hadits no. 2129, h. 1182.

2 Infertilitas, atau 'ajzi an al-injâb adalah ketidak mampuan seorang pria atau wanita untuk menghasilkan anak. Penyebabnya sangat beragam. Pada pria, kemandulan bisa disebabkan oleh gangguan organ reproduksi seperti testis (skrotmm) rusak, sehingga sperma yang dihasilkan jelek, saluran tersumbat dan sebagainnya. Sedang penyebab kemandulan pada wanita bisa lebih beragam. Antara lain gangguan pada organ reproduksinya, seperti indung telur, saluran telur tersumbat, infeksi rahim, endometriosis, miom, gangguan hormon dan sebagainya. Kemandulan juga dapat disebabkan oleh adanya gangguan organ tubuh yang lain seperti kelainan selaput otak, ginjal, hati, dan lain-lain yang akan mempengaruhi fungsi normal alat kandungan. Lihat Majalah Ayah Bunda, majalah pasangan muda, no. 11, 3-16 Juni 1995, h. 58. Lihat juga Muhammad Imarah, Al-A 'mal al-Kâmilah li al-Imâm al-Syeikh Muhammad Abduh II, Kairo: Dar al-Syurq, 1993, h. 85.

3 Imarah, ibid., h. 83.

4 Ibid.

5 Al-Waqâi “ al-Mishriyah Edisi yang diterbitkan pada tanggal 8 Rabi' al-Awwal $1298 \mathrm{H}$. Dalam Edisi ini Abduh menjelaskan secara jelas tentang sikapnya terhadap masalah poligami. Lihat Tafsir al-Manâr $N$, h. 460; Muhammad Imarah, ibid., h. 67.

6 Ibid.

7 Rasyid Ridla, $N$, Op.Cit., 368.

8 Imarah $I I$, Op.Cit., h. 80

9 Ibid., h. 81.

10 Ibid.

1 Ibid., h. 76

12 Ibid, h. 77. Abduh di sini tidak menyebutkan rawi dari riwayat-riwayat di atas. Adapun hadits tentang ancaman Rasulullah terhadap yang tidak berlaku adil dalam berpoligami itu adalah diriwayatkanoleh lima perawi (rawahu al-Khamsah) dari Abu Hurairah, lafazhnya ada di Abu Daud.

13 lbid, 163.

Ulul Albab, Vol. 3 No. 2, 2001 
14 Muhammad Imarah, V Op. Cit., h. 163.yang diriwayatkan dari 'Urwah ibn al-Zubair. Lebih jelasnya lihat Rasyid Ridla, Tafsîr al-Manôr $I V$, h. 344-348.

is Cukup banyak riwayat yang menjelaskan tentang asbab al muzul ayat ini, di antaranya tedapat dalam Bukhari, Muslim, Nasa'i, Baihaqqi, Ibnu Jarir al-Thabari, Ibnu al-Mundzir, Ibnu Abi Hatim

16 Muhammad Imarah, Al-Imâm Muhammad Abduh Mujaddid Dunya bi tajdidi al-Dîn, Kairo: Dar al-Syurq 1988 h. 250-253.

17 Mahmud Syaltut, Al-Islam Aqîdah wa al-Syarîah, Kairo: Dar al-Syurq 1992, h. 180.

18 Ibid., 183.

19 Ibid., h. 184.

20 Ibid., h. 187.

21 Ibid., h. 185.

22 Ibid., h., 188.

23 Ibid., 189

24 Syaltut tidak menyebutkan matan hadits-hadits tersebut. Mungkin yang dimaksudkan adalah di antaranya riwayat-riwayat yang juga disebut Abduh pada pembahasan yang lalu. Lebih jelasnya lihat Muhammad Imarah, $A l-A$ 'mal al-Kamilah ... II, h. 77.

25 Syaltut juga tidak menyebut siapa fuqaha' yang ia maksudkan

26 Syaltut, Op Cit., h. 190.

27 Ibid., h. 191.

28 Ibid.

29 Tbid, h. 192.

30 Ibid., 194.

31 Muhammad Shaleh al-Marâkîsy, Tafkìr Muhammad Rasyîd Ridlâ min Khilâ Majallah al-Manar (1898-1935), Tunisia: Al-Dâr al-Tunisia li al-Nasyr 1985, h. 338

32 Syahrûr punya pandangan menarik tentang diskursus poligami ini, khususnya yang berkait dengan poligami dengan janda. Lihat Muhammad Syahrûr, Al-Kitab wa alQur'an, Kairo: Sina Publisher 1992, h. 597-598

33 Ahmad Mustafa al-Marâghi, Tafsîr al-Marâghi II. Dar al-Fikr li al-Thaba'ah wa alNasyr wa al-Tauzit h.181. Di sini ia banyak mengungkap hal-hal penting yang menurutnya perlu dipertimbangkan dalam kaitannya dengan poligami.

34 Yusuf Wibisono, Monogami atau Poligami Masalah Sepanjang Masa, Jakarta: Bulan Bintang 1980, h. 53.

35 Ibid., h. 55. 
36 Untuk lebih jelasnya bagaimana persaingan dan konflik itu terjadi di kalangan Ummu al- Mu'minin tersebut, lihat 'Aisyah Bintu Syâthi', Nisâ' al-Nabi (Istri-istri Nabi Fenomena Poligami di Mata Seorang Tokoh Wanita -oleh Abdullah Zaki al-Kaf), Bandung: Pustaka Hidayah 2001, h. 97-110.

37. Komentar ini dikutip Asghar dari Maulana Muhammad Ali dalam The Holly al-Qur'con. Lihat Asghar Ali Engineer, The Right of Women in Islam (dalam edisi Indonesianya: Hak-Hak Perempuan dalam Islam, oleh Farid Wajidi dan Cici Farkha Assegaf, Ygyakarta: LSPPA 2000, h. 154.

38 Ibid., h. 155.

39 Ibid, 157. 